\title{
Wiele desygnatów, jedna (specjalistyczna) funkcja? W sprawie terminów i znaków bizantyjskiej notacji ekfonetycznej
}

\author{
Grzegorz Pawłowski \\ Uniwersytet Warszawski \\ Polska \\ ORCID: 0000-0002-2465-2906 \\ g.pawlowski@uw.edu.pl
}

G. Pawłowski, Many designations, one (specialized) function? Regarding the terms and signs of Byzantine ekphonetic notation, Elpis, 21 2019: 71-77.

G. Pawłowski, Wiele desygnatów, jedna (specjalistyczna) funkcja? W sprawie terminów i znaków bizantyjskiej notacji ekfonetycznej, Elpis, 21 2019: 71-77.

\begin{abstract}
This article treats of monosemy and polisemy. We speak about polisemy as referring to both the reception of words and the mental constitution of lexemes in the so called cognitive domain or cognitive frame. A lexeme not only establishes its position in the frame, but also activates the frame. The activation of a lexeme into the operational memory has an event occurrence character, as it is in fact a series of neurons' flashes. Hence one ought to associate the meaning of a lexeme with its event related (specialized) function. This specialized function comes into existence by means of cognitive acts, which are effectuated by a concrete subject relative to previously defined aims. Key are those acts that lead to the consolidation of the function in the long term memory of the subject. The cognitive acts can be effectuated not only as a result of the acquisition of knowledge, but also on the basis of the knowledge already consolidated, thus enabling the creation of new knowledge, i.e. such knowledge that was not in the mental space of the subject prior to the termination of the cognitive acts' sequence. In either case, the (specialized) function (of a lexeme), i.e. a concrete result of cognitive acts, will be a one-time event. This conclusion is exemplified by identification, interpretation and the construction of Polish specialized lexemes in the field of ekphonetic notation, which constitutes a part of the Byzantine music tradition and hymnography.

Streszczenie: Niniejszy artykuł jest poświęcony kwestii wielo- i jednoznaczności. O wieloznaczności mówimy zarówno w odniesieniu do recepcji wyrazu, jak i do mentalnego umocowania leksemu w tak zwanej kognitywnej domenie lub ramie. Leksem nie tylko się w tej ramie konstytuuje, lecz ją także aktywuje. W perspektywie aktywacji leksemu do pamięci operacyjnej, które ma charakter zdarzeniowy - jest on bowiem w (swej) istocie ciągiem neuronowych błysków -, powinniśmy utożsamiać jego znaczenie ze zdarzeniową funkcją (specjalistyczną), w jakiej został aktywowany. Na konstytuowanie się tej funkcji mają wpływ akty poznawcze, które realizuje konkretny poznający podmiot ze względu na zdefiniowane wcześniej cele. Kluczowe są te akty, które prowadzą do konsolidacji tej funkcji w pamięci długotrwałej tegoż podmiotu. Akty poznawcze mogą być przy tym realizowane nie tylko w wyniku akwizycji wiedzy, mogą się one dokonywać także na bazie wiedzy już skonsolidowanej i zmierzać w związku z tym do wytworzenia nowej wiedzy - a więc wiedzy, której w przestrzeni mentalnej podmiotu do chwili zakończenia danego ciągu tych aktów jeszcze nie było. W obu przypadkach (specjalistyczna) funkcja (leksemu), a więc konkretny poznawczy wynik poznawczych aktów, będzie jednorazowa. Tę kwestię przedstawiam na przykładzie identyfikacji, interpretacji i konstrukcji polskich leksemów specjalistycznych z zakresu notacji ekfonetycznej, będącej częścią tradycji muzyki i hymnografii bizantyjskiej.
\end{abstract}

Keywords: specialized function of expression, term, Byzantine notation, neologism

Słowa kluczowe: znaczenie, specjalistyczna funkcja wyrazu, termin, notacja bizantyjska, neologizm

\section{Wstęp}

Lingwiści zgadzają się zazwyczaj co do tego, iż jeden wyraz może odsyłać do wielu desygnatów. W płaszczyźnie mentalnej wieloznaczność danego leksemu wiązana jest przez nich najczęściej z wielością tak zwanych „domen” czy też „(semantycznych) ram”, w jakich ten leksem uczestniczy lub jakie on sam bądź też wespół z innymi leksemami konstytuuje (Kotin, 2016). Atoli biorąc pod uwagę status ontologiczny leksemu, w szczególności fakt, iż jego aktywacja do pamięci operacyjnej ma charakter akcydentalny - sprowadza się ona bowiem do ciągu (neuronalnych) błysków - należałoby wiązać „,warstwę zna- czeniową" tegoż leksemu z jednorazową (specjalistyczną) funkcją, w jakiej został aktywowany, aniżeli utożsamiać jego eksponenty, tzn. wyrazy, ze znaczeniem, którego te ze swej istoty (w dosłownym sensie) posiadać po prostu nie mogą. Kluczowe dla tej funkcji są akty poznawcze realizowane przez konkretny podmiot; szczególnie zaś te akty poznawcze, które prowadzą do konsolidacji tej funkcji w jego pamięci długotrwałej. Jednak niezależnie od tego, czy będą to akty wynikające z absorpcji (wiedzy), czy też akty zmierzające do wytworzenia nowej wiedzy na podstawie już skonsolidowanej, to (specjalistyczna) funkcja (leksemu), a więc konkretny poznawczy wynik tych aktów, będzie w płaszczyźnie neuronalnej jednorazowa. 
Rozważając funkcje teleologiczne leksemu - elementu mentalnego oraz wyrazu - jego wyrażeniowej reprezentacji, zwracam w kontekście tematu niniejszego artykułu uwagę na kwestie dotyczące pracy poznawczej człowieka, w szczególności jego poznawczych aktów, które w płaszczyźnie przetwarzania wiedzy na poziomie komunikacji interneuronalnej są według neurobiologów niepowtarzalne (Siegel, 2006; Welzer, 2006; Domasch, 2007; Borck 2005). Nie można tego zignorować, rozważając problemy związane z językową pracą poznawczą człowieka, i to zarówno w odniesieniu do absorpcji (wiedzy), tzn. internalizacji wyrazu i jego funkcji, jak i w odniesieniu do wytwarzania nowej wiedzy, tzn. konstrukcji nowego leksemu i jego nowej funkcji. Obierając perspektywę idiocentryczną skupię się na dwóch kwestiach: (1) identyfikacja ciągów grafemowych i fonemowych i ich interpretacja jako ciągów odsyłających do konkretnych desygnatów, tzn. do konkretnych (specjalistycznych) funkcji, oraz (2) konstrukcja nowych ciągów grafemowych i fonemowych, ściślej mówiąc, konstrukcja nowych leksemów ze szczególnym uwzględnieniem nowych (specjalistycznych) funkcji tych leksemów. ${ }^{1}$

\section{Identyfikacja wyrazów, ich desygnatów i (specjalistycznych) funkcji}

Wyjdźmy na początek od identyfikacji następującego ciągu grafemów (1):

(1) (Leningrad Codex, Westminster 2006, Rdz 1,1).

Jeżeli zinternalizowaliśmy ciągi tych grafemów jako elementy jakiegoś systemu, ściślej logicznego eksponentu jakiejś kulturowej, a zarazem językowej wspólnoty, to wiemy między innymi, że taki grafem jak np. $<$ i $>$ spełnia morfologicznie funkcję rodzajnika, fonologicznie zaś należy zaś do grupy (bezdźwięcznych) fonemów gardłowych, będących w repertuarze bardzo wielu językowych wspólnot. Rozpatrując powyższy ciąg grafemów w perspektywie wiązanych z nimi znaczeń, tzn. wiązanych z nimi (możliwych) desygnatów oraz konkretnych funkcji, można przy-

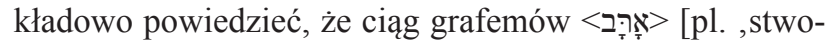
rzył'] to 3. os. czasu przeszłego liczby pojedynczej rodzaju męskiego od średnio-hebrajskiego czasownika $>$ ארב $>$. Ten czasownik w znaczeniu ,stwarzać', ,formować/ nadawać kształt' pełni w Starym Testamencie funkcję terminu teologicznego, „(...) którego podmiotem jest niezmiennie Bóg." (zob. m.in. Iz 40,28 krańce ziemi; Iz 42,5; 45, 18 niebo; Iz 65,17 nowe niebo i nowa ziemię; Ps 89,13 pótnoc i poludnie; Iz 40,26 gwiazdy, Rdz 1,27 czlowieka, mężczy-

Cudzysłów francuski «...» stosuje się w niniejszym tekście dla oznaczenia «znaków» notacji oraz desygnatów omawianej nazwy lub omawianego terminu. Thumaczenia terminów podawane są w cudzysłowiu prostym ,...' Nawiasami ostrymi nawiasami $<\ldots>$ oznacza się (ciągi) grafemowe. znę i kobiete, por. WSHA, t. 1, 145). Termin teologiczny, jak chcą Autorzy Wielkiego Stownika, to w metajęzyku lingwistyki wyraz, lub grupa wyrazów, spełniająca w jakiejś ramie (względnie) jasno określone funkcje. Klasycznie funkcje te wiązane są z semantyką, pragmatyką i składnią danego języka, natomiast $\mathrm{w}$ odniesieniu do lingwistyki tekstu i języków specjalistycznych także z typem/ rodzajem tekstu (niem. ,Textsorte'), w którym takie funkcje się konstytuują. Biorąc pod uwagę definicje leksykograficzne czasownika ארב $>$, któremu przypisuje się wiele desygnatów, takich jak «utuczyć się (ponad miarę)», «nadawać kształt przez cięcie», «wycinać», «czyścić» (por. KWAH, s. 45; WHB, s. 186-187), zastanawia, dlaczego wiązany jest on w Starym Testamencie semantycznie, składniowo, tekstologicznie, lecz przede wszystkim logicznie, z podmiotem «Bóg» w jednej (specjalistycznej) funkcji? I choć Podmiot ten wyrażany jest za pomocą różnych wyrazów

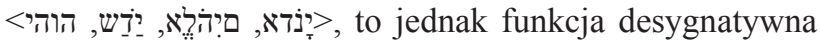
tych wyrazów jest zasadniczo analogiczna. Wśród wymienionych wyrazów zwraca uwagę nazwa własna $>$ הוהיל. Pominąwszy fakt, iż jest ona pozbawiona wokalizacji - jej wymowa jest w związku z tym hipotetyczna, choć raz do roku praktykowana -, można z całą pewnością stwierdzić, że stanowi ona w tekstach Starego Testamentu indykator (grafemowy), dzięki któremu dokonujemy jednoznacznej identyfikacji podmiotu zdania, w którym została ona użyta.

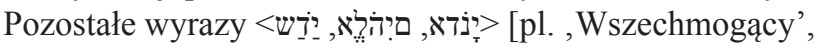
,Bóg', ,Pan'], pełnią co prawda funkcje nazw własnych, $\mathrm{w}$ istocie jednak nazwami własnymi w ścisłym rozumieniu nie są (HAWAT, s. 4, 18, 47, 485), tzn. nie są częścią mowy taką jak (epo-)onim. (Nagórka, 2017, s. 74 - 82).

Wróćmy do kwestii identyfikacji grafemów i przyjrzyjmy się greckiemu translatowi cytowanego wyżej tekstu hebrajskiego (2).

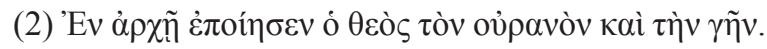
(LXX Editio altera, Rdz 1,1)".

Nawet niewprawione oko dostrzeże tutaj różnice strukturalne, polegające na tym, że tekst hebrajski jest bardziej syntetyczny, aniżeli jego grecki translat. Wynika to między

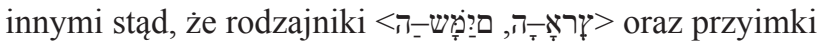
$>$ תישאר --ב pisane są w hebrajskim łącznie, w greckim zaś

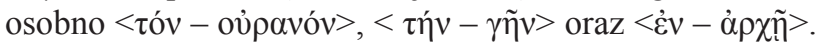
Oko bardziej wprawione dostrzeże w obu tekstach grafemy reprezentujące gardłowe spiranty, mam tu na myśli $\langle\pi\rangle$ oraz $\left\langle\left\langle^{\prime}\right\rangle\right.$. W czasie formowania się Nowego Testamentu spirant grecki, który określamy terminem spiritus asper [pl. , przydech mocny'], nie był wprawdzie obecny w mowie, był jakkolwiek wciąż używany w piśmie aż do reformy w 1982 r., kiedy to wraz z innymi znakami diakrytycznymi, takimi jak «akut», «gravis», «cyrkumfleks» $\mathrm{i}$ «jota subskcriptum», został ostatecznie wyłączony z oficjalnej ortografii (Kausen, 2010, s. $388-390$ ). ${ }^{2}$ Taka sytuacja nie

Pomimo wprowadzonej reformy konserwatywne środowiska (akademickie), do których zaliczają się w swej znaczącej większości także naukowcy, zajmujący się hymnografią i muzyką bizantyjską, wciąż stosują zasady ortografii pisowni sprzed reformy. 
zachodzi w hebrajskim. Nie zachodzi ona, rzecz jasna, także w translacie polskim, ponieważ ani przydech mocny, ani wspomniane wyżej rodzajniki w ścisłym rozumieniu tego słowa w języku polskim nie występują (3).

(3) Na początku Bóg stworzył niebo i ziemię (Biblia Poznańska 1974/75, Rdz 1,1).

Identyfikując cytowane wyżej ciągi grafemowe jako znaczące, bez większego trudu odnajdziemy także różnice w planie morfologicznym, semantycznym, w tym etymologicznym, czy też różnice pragmatyczne, np. różnice, do-

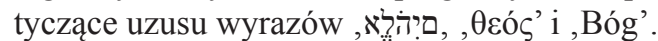

Przejdźmy zatem do interpretacji ciągów grafemowych na poziomie znaczeń. Wyrazy, jakie posłużą nam za ilustrację, konstytuują płaszczyznę terminologiczną notacji muzycznej, która została wymieniona w tytule niniejszego artykułu. Spójrzmy najpierw na następujące wyrazy:

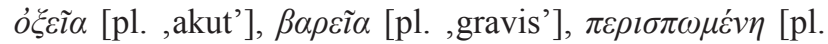
,cyrkumfleks']. Wyrazy te odwoływały hellenistycznych (i późniejszych) Greków do grupy tak zwanych znaków

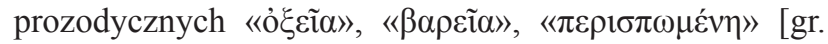

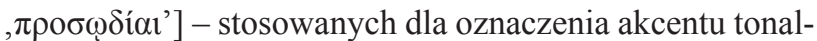
nego (LSJ, s. 1532 - 1533; SGP, s. 835; GLRBP, s. 952). Genezę znaków upatruje się w osobie helleńskiego filozofa i gramatyka, Arystofanesa z Bizancjum (ok. 257 - 180 przed Chr.), któremu przypisuje się nie tylko wynalezienie znaków, lecz także ich klasyfikację oraz zdefiniowanie poszczególnych desygnatów tychże znaków. Nie można jednak pominąć faktu, że już Arystoteles odróżniał pomiędzy $\delta \xi \xi \varepsilon \tilde{i} \alpha$ [pl. ,wysoki'], $\beta \alpha \rho \varepsilon i \alpha$ [pl. ,niski'] a $\mu \delta \dot{\varepsilon} \sigma \eta$ [pl. ,pośredni'] (Arystoteles, Retoryka 1403b 29; także Callanan, 1987, s. 31, 32; Wellesz, 1961, s. 249; Brandenburg, 2005, s. 34 - 35). W późniejszym czasie znaki prozodyczne, uzu-

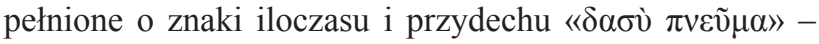

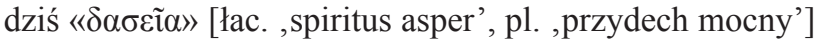

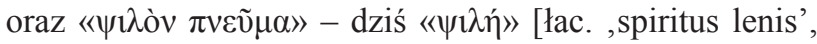
pl. ,przydech słaby'] oraz odpowiadające im nazwy $\delta \alpha \sigma \grave{v}$ $\pi v \varepsilon \tilde{v} \mu \alpha$ i $\psi \imath \lambda \hat{o} v \pi v \varepsilon \tilde{v} \mu \alpha$, były stosowane dla celów retorycznych, w szczególności w ramach sztuki poprawnej deklamacji. Należy tutaj przypomnieć, że retoryczny element (metrum) stanowiła także cezura [gr. , $\tau$ o $\mu$ '́, graficznie

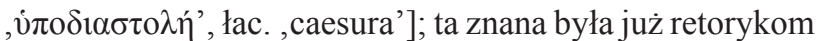
Grecji klasycznej. Wspominam o tym, ponieważ cezura rzecz jasna nie $\mathrm{w}$ tak rygorystycznej formie, jak to miało miejsce w tekstach klasycznych - przetrwała do czasów bizantyjskich, zaś w księgach liturgicznych była dodatko-

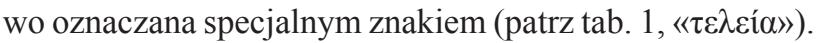
Ten fakt nie powinien nikogo dziwić, bowiem w początkowym okresie kształtowania się bizantyjskiej kultury, tj. od około 600 r. po Chr., cały inwentarz znaków prozodycznych posłużył jako podstawa dla opracowania znaków muzycznej notacji wczesnobizantyjskiej, tak zwanej nota-

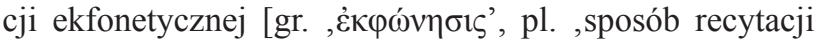

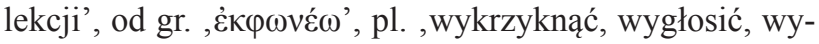
powiedzieć'], z której poczynając od XII w. rozwinął się właściwy system notacji muzycznej, tzw. system średnioi późno-bizantyjski, zwany inaczej notacją hagiopolitańską
(XII w.) i kukuzeliańską (XIV w.) (Hannick, 1995, s. 298; Alexandru, 2006, s. 119; Wellesz, 2006, s. 286 - 288).

Prześledźmy w związku z tym kwestię (późniejszej) interpretacji wymienionych wyżej wyrazów używanych do określania znaków prozodycznych, to znaczy kwestię interpretacji tego, jak zmieniły się ich desygnaty w kulturze bizantyjskiej, ściślej mówiąc, w kulturze bizantyjskiego śpiewu liturgicznego. System notacji ekfonetycznej skła-

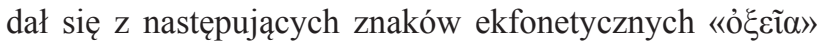

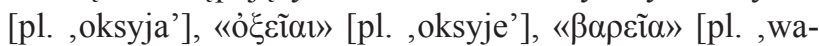

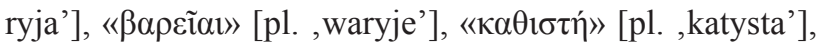

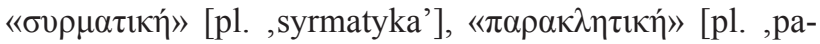

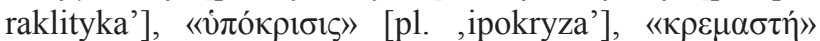

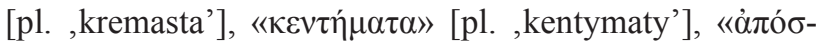
$\tau \rho о \varphi о \varsigma »$ [pl. , apostrofos'], «ஷ̉

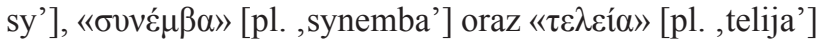

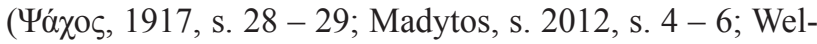
lesz, 2006, s. 274 - 277; Wellesz, 1961, s. 250 - 252; Haas, 1973, s. 112; Hannick, 1995, s. 293, 298; Alexandru, 1999, s. 16; Nikolakopoulos, 2015, s. 449; Richter, 1998, s. 135; Engberg, 1982, s. 41; LLKO, s. 288). ${ }^{3}$ Poniżej przedstawiam «znaki» tej notacji i odpowiadające im ,nazwy', tzn. ,terminy’.

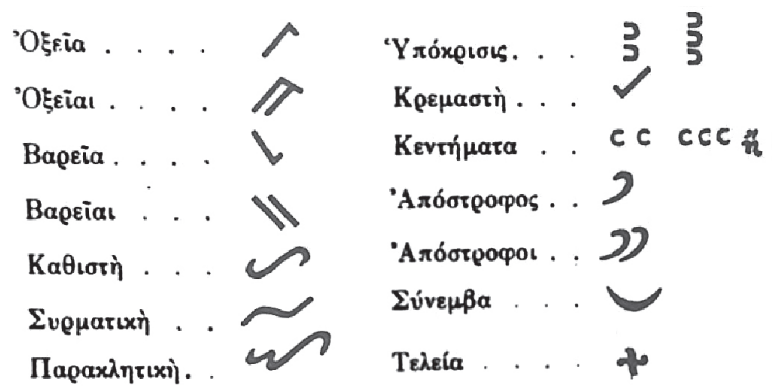

Tab. 1. System notacji ekfonetycznej

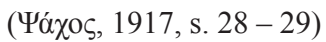

O ile w powyższym systemie notacji wyrazy $\delta \xi \varepsilon \tilde{c} \alpha$ i $\beta \alpha \rho \varepsilon \tilde{i} \alpha$ otrzymują jedynie swoje formy mnogie $\delta \xi \varepsilon \tilde{l} \alpha l$ i $\beta \alpha \rho \varepsilon \tilde{\alpha} \alpha$ - ich desygnaty pozostają zasadniczo takie same,

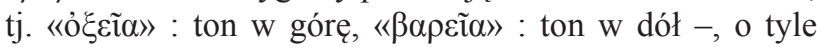

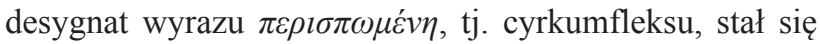
najprawdopodobniej bazą dla dyferencji znaków wtórnych [gr. , $\pi \varepsilon \rho \iota \sigma \pi \alpha ́ \omega ', p l$, ściągać, wyciągać, wymawiać z cyrkumfleksem'] (SGP, s. 760; LSJ, s. 1386). Wyraża się ona zarówno w zakresie znaczeniowym wyrazu, ściślej, muzykologicznego terminu, jak i w formie samego prozodycz-

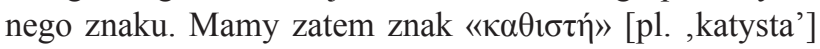
oznaczający styl narracji pozbawiony emfazy - zwykle na początku czytania Ewangelii poprzedzonego słowa-

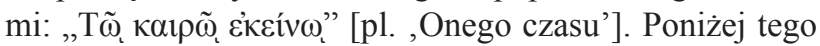

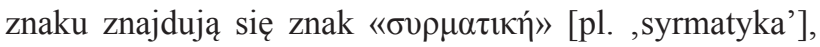

3 Doskonałej adaptacji terminów hymnografii i muzyki bizantyjskiej greckiej proweniencji do języka polskiego dokonał Maciej Kaziński. Polskie terminy z tego zakresu znalazły się w ogłoszonej w 2006 r. i przethumaczonej przez niego monografii pt. Historia muzyki i hymnografii bizantyjskiej autorstwa Egona Wellesza. W kwestii normalizacji polskich terminów por. także Kostiuczuk i in., 2016 oraz Paprocki, 2014. 
który oznaczał falujący ruch głosu podobny do kształtu

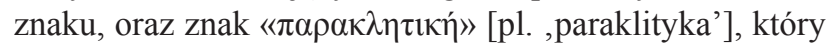
oznaczał frazę wykonaną w sposób błagalny, modlitewny. Znak, za pomocą którego oznaczano pauzę/ cezurę, czyli «نं tywowanym bez wątpienia kulturą chrześcijańską. Mam tu

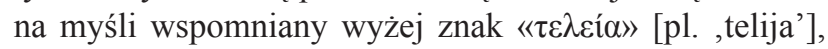

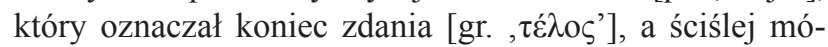
wiąc, przerwę w melodycznej deklamacji tekstu (Madytos, 2012, s. 15).

Jeśli przyjrzymy się pierwotnym znakom charakte-

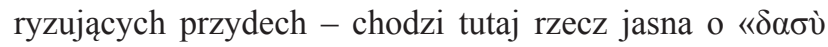

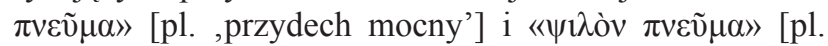
,przydech słaby'] -, to zauważymy, że zbliżone są one

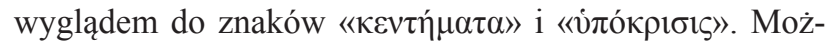
na by je w związku z tym potraktować jako antropologiczną bazę dla wykreowania (specjalistycznej) funkcji

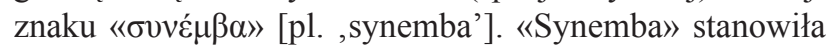
bowiem rodzaj ligatury łączącej dwa słowa na jednym oddechu. (Wellesz, 2006, s. 278-279). Na przykładzie

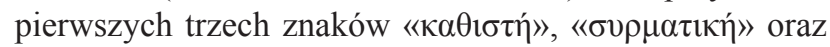

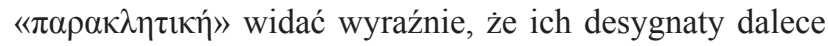
wykraczają poza te, do jakich odwoływał bizantyjskich

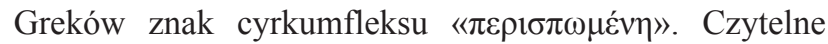
jest także to, iż stanowią one dowód pracy poznawczej zmierzającej do dyferencjacji, a w konsekwencji, do wydzielenia z zakresu znaczenia pierwotnego cyrkumfleksu nowych (zakresowo) węższych desygnatów. Ponieważ znaki «katysta», «syrmatyka» i «paraklityka» stanowią część całego systemu specjalistycznej notacji muzycznej, tzn. specjalistycznej ramy, należy uznać odpowiadające im wyrazy katysta, syrmatyka i paraklityka za specjalistyczne, ściślej, wiązane z nimi funkcje jako funkcje specjalistyczne. O pozostałych znakach i wyrazach, które konstytuują system bizantyjskiej notacji ekfonetycznej, można powiedzieć zasadniczo to samo, to znaczy, że spełniają funkcje, jakie poszczególne (narodowe i międzynarodowe) komitety normalizacji przypisują jednostkom terminologicznym (terminom).

\section{Konstrukcja nowych funkcji specjalistycznych}

Konstrukcję nowych leksemów specjalistycznych zilu-

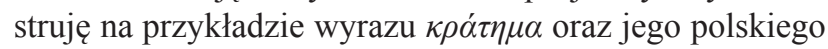
odpowiednika, neologizmu specjalistycznego. Na początek poczynię kilka uwag dotyczących historii tego wyrazu. Biorąc pod uwagę okres dzielący grekę klasyczną od greki bizantyjskiej ( 800 r. przed Chr. - 600 r. po Chr.) rzeczow-

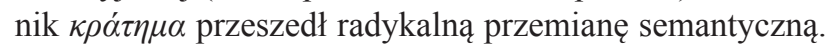

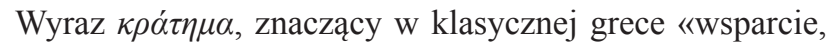

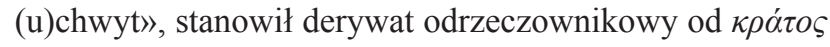
[pl. ,moc, siła, potęga, władza, przewaga, zwycięstwo']. Od tego rzeczownika pochodzi najprawdopodobniej cza-

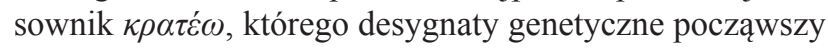
od Iliady Homera nie odbiegają zasadniczo od desygnatów

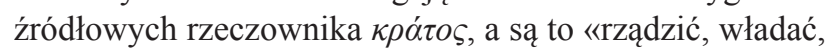

panować, podbijać». Ciekawi jednakowoż fakt, iż cza-

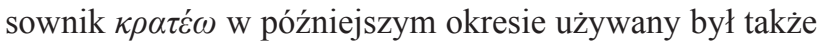
w funkcji, która nas tutaj najbardziej interesuje, a mianowicie w specjalistycznej funkcji «przedłużać» $(\mathrm{OH}, \mathrm{s} .52$ niem. ,zeitlich verlängern', por. także LSJ, s. 991 ang. ,endure, put up with'; SGP, s. 554 - 555 pl. ,trwać (przy czymś)'; $\Lambda$ ОГЕION ang. ,hold up'; GEW, t. 2, s. 8 -10). Ta funkcja jest istotna nie tylko dla rozumienia desygnatu

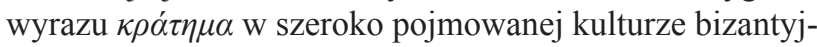
skiej (GLRBP, s. 689 ang. ,seize, arrest, apprehend'), ale także dla jego rozumienia w muzyce i hymnografii bizantyjskiej. Muzyka i hymnografia stanowi bowiem węższy specjalistyczny zakres kultury tamtego okresu, jest zatem

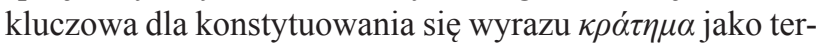
minu.

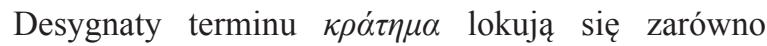
w ramie muzykologicznej, jak i w ramie hymnograficznej, konstytuują one w związku z tym dwie specjalistyczne kategorie, będące jakkolwiek częścią jednej dyscypliny.

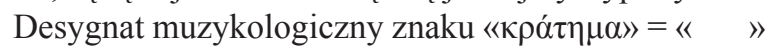

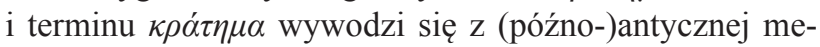
tryki, gramatyki i retoryki. Znak i termin używany był w znaczeniu «przedłużać» (Alexandru, 1999, s. 10). Znak

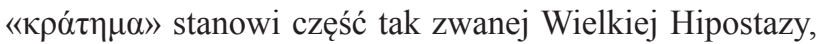
tj. znaków cheironomicznych późnej notacji bizantyjskiej.

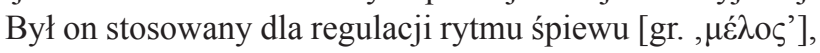
podwajał mianowicie wartość rytmiczną neumy [gr. , $v \varepsilon v \tilde{\mu} \alpha$ ', pl. ,skinienie', ,znak'], przy której był umieszczany. Specjalistyczna funkcja tego znaku odnosi się także do sposobu śpiewu chóru psaltów [gr. , $\psi \alpha \alpha ́ \lambda \tau \eta \varsigma^{\prime}$ ], tzn. pra-

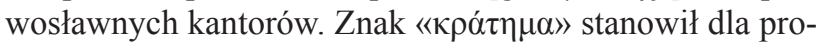

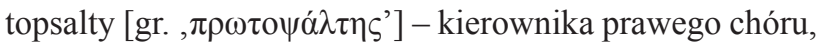
oraz dla lampadariusza [gr. , $\lambda \alpha \mu \pi \alpha \delta \alpha \alpha_{\rho}$ lewego chóru, wskazówkę, że śpiew w tym miejscu powinien być emfatyczny, mocny, silny (Haas, 1973, s. 24 28; Wellesz, 1961, s. 294; Georgiades, 1939, s. 77). Liczba mnoga $\kappa \rho \alpha \tau \dot{\mu} \mu \alpha \tau \alpha$ spełniała funkcję hiperonimu, obejmującego dwa pozostałe znaki rytmiczne o analogicznej funk-

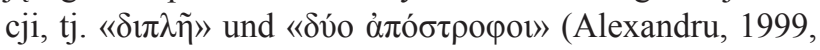
s. $4-5$; 1998a, s. 30; Wellesz, 1961, s. 295).

Jeżeli chodzi o desygnat hymnograficzny terminu $\kappa \rho \dot{\alpha} \tau \eta \mu \alpha$ to jest to muzyczna kompozycja śpiewana po

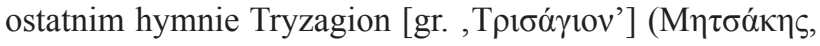

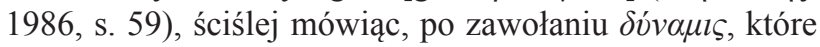
wychodzi z ust diakona po to, aby psalci obu chórów mogli zaintonować melizmatyczną kompozycję, bardzo wolno śpiewanych ekfonetycznych sylab takich, jak $<\tau \varepsilon \rho \imath \rho \varepsilon \mu>$, $<$ vovo $>,\langle\tau$ , $\varepsilon \rho \varepsilon \tau \imath \sigma \mu$ oí', Hannick, 1995, s. 296; OH, s. 52; Wolfram, 2000, s. 57; Hannick, 1995, s. 296; GEW, t. 1, s. 423 - 424;

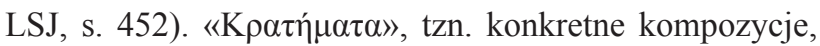
nawiązują do melodii [gr. , $\mu \varepsilon ́ \lambda o \varsigma^{\prime}$ ] hymnu Tryzagion, i są dosłownie jego melizmatyczną syntezą.

Konstrukcję polskiego leksemu specjalistycznego, wyrażonego za pomocą specjalistycznego neologizmu kratemat zawdzięczamy wspomnianemu wyżej thumaczowi, Maciejowi Kazińskiemu, który wprowadził go do ususu w polskim translacie opiniotwórczej monografii profeso- 
ra Egona Wellesza pt. A History of Byzantine Music and Hymnography. Pominę tutaj aspekt morfologiczny procesu konstrukcji tego leksemu (Pawłowski, 2017a, s. 243-250, s. 414 - 421). Należy jakkolwiek zaznaczyć, iż autor tekstu wyjściowego, Egon Wellesz, używa angielskiego ter-

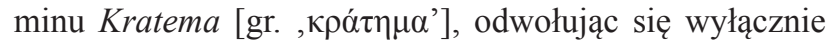
do desygnatu muzykologicznego, a więc do rytmicznego

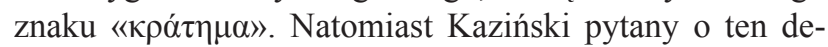
sygnat $\mathrm{w}$ jednym $\mathrm{z}$ przeprowadzonych $\mathrm{z}$ nim wywiadów, stwierdza, że go po prostu nie pamięta (patrz fragment wywiadu poniżej, WMK05). Wyrażenie kratemat definiuje on mianowicie wyłącznie, odwołując się do ramy hymnograficznej, a więc do melizmatycznej kompozycji. Należy zatem wnioskować, że funkcje, jakie wiąże on z leksemem specjalistycznym kratemat w chwili odpowiedzi na zadane pytanie, odnoszą się do jego doświadczenia jako psalty - mającego w swoim doświadczeniu publiczne wykonywanie melizmatycznego hymn Tryzagion, nie zaś do jego doświadczenia jako tłumacza tekstów specjalistycznych. Tłumacząc tekst Egona Wellesza Kaziński musiał przecież zinternalizować także funkcję muzykologiczną terminu $\kappa \rho \alpha ́ \tau \eta \mu \alpha$, wtórnie zaś muzykologiczną funkcję specjalistycznego leksemu kratemat (por. m.in. A $\beta \alpha v i ́ t n s, ~ 2010$, s. 197-201), a w związku z tym konkretnego specjalistycznego pojęcia, tzn. jednostki mentalnej, którą w konkretnej specjalistycznej ramie (jako specjalista) zarządza. Dodam, że wyrażenie specjalistyczne kratemat do czasu opublikowania translatu nie istniało $\mathrm{w}$ piśmiennictwie polskojęzycznym, dlatego należy je, podobnie jak pozostałe 148, traktować jako neologizmy specjalistyczne (szczegółowo na ten temat zob. Pawłowski, 2017a, s. 188-190, 2017b, s. $98 ; 2018$, s. 53-61; 2015b, s. 165-176).

WMK05 $\{11: 54\}$ RB11 GP y $<<$ all $>$ czy przypominasz sobie $\uparrow$ DRUGIE znaczenie tego słowa ${ }^{-}>$

WMK05 \{11:57\} RB12 MK (1.3) ((mlaśnięcie)) (1.5) ` hh NIE` (1.0)

WMK05 \{12:02\} RB13 GP m::: znak (.) y: (-) y:: y:: 'RYTMICZNY

WMK05 $\{12: 07\}$ RB14 MK (3.1) $<<$ p $>$ nie 'przypoMINAM sobie' $>$

\section{Wniosek}

Obecny stan wiedzy w zakresie pracy centralnego systemu nerwowego oraz wyniki ewaluacji wywiadów $\mathrm{z}$ thumaczem pozwalają twierdzić, iż proces konstrukcji leksemu specjalistycznego różni się od procesu jego wywoływania z pamięci długotrwałej do pamięci operacyjnej (Rudy, 2014, s. 205 - 215, s. 233 - 239, 270; Heidler, 2013, s. 5, 78 - 80; Kahana, 2012, s. 146; Kowalska, 1997, s. 298 - 299; Eichenbaum, 2012, s. 317). Oba procesy łączy jednakowoż fundament poznawczy, to znaczy rzeczywiste elementy wiedzy ufundowane genetycznie, kulturowo i/ lub aksjologicznie (zob. niem. ,Erkenntnisbasis', Pawłowski 2017, s. 34 - 48). Dla aktywacji specjalistycznej funkcji danego leksemu kluczowe jest w obu przypadkach do- świadczenie podmiotu poznania. Oba procesy łączy także to, że każdorazowa aktywacja specjalistycznej funkcji danego leksemu odbywa się w czasie i, co najistotniejsze, zawsze w konkretnej wewnętrznej ramie specjalistycznej, co implikuje jego (temporalną) jednoznaczność. Co do różnic w tym zakresie, to dotyczą one przede wszystkim funkcji mentalnych podmiotu, jakie ten aktywuje w kontekście podejmowanych przez siebie (poznawczych) zadań. W procesie aktywacji leksemu do pamięci operacyjnej są to akty kognitywne, w procesie jego konstrukcji są to akty ściśle poznawcze (epistemiczne). Wynikiem tych ostatnich jest bowiem zasadniczo nowa wiedza (szczegółowo na temat funkcji kognitywnych i epistemicznych por. Pawłowski, 2015a). Warto w tym miejscu dodać, że w przestrzeni mentalnej podmiotu nie może zaistnieć żadna nowa funkcja, tym bardziej nowa funkcja specjalistyczna, o ile ten podmiot jej sam wcześniej nie wytworzy, już to na podstawie wyrazu, już to odnosząc się do doświadczenia z konkretną (specjalistyczną) referencją.

\section{Konkluzja}

Jak należy rozumieć powyższy wniosek w kontekście tytułowego pytania, Wiele desygnatów, jedna (specjalistyczna) funkcja?' O ile z perspektywy policentrycznej desygnaty wyrazu, w tym także terminu, mogą być i są zazwyczaj różne, o tyle w perspektywie idiocentrycznej leksem wywołany do pamięci operacyjnej - wywołany do konkretnej (wewnętrznej) ramy, aktywuje zasadniczo tylko jedną funkcję, i to zarówno w chwili jego recepcji (identyfikacji i interpretacji), jak również $\mathrm{w}$ chwili jego produkcji (artykulacji). Mamy innymi słowy ,po stronie' ewidencji korpusowej wiele różnych desygnatów jakiegoś wyrażenia, jesteśmy natomiast konfrontowani ,po stronie' konstytuowania się leksemów, tj. po stronie rzeczywistych faktów mentalnych realizowanych w konkretnym czasie i w konkretnej (specjalistycznej) ramie, z funkcją, której status w tymże czasie i w tejże (specjalistycznej) ramie jest jednorazowy. Jeżeli w przypadku komunikowania tej funkcji za sprawą aktach językowych mielibyśmy jeszcze jakieś resztki wątpliwości (diagnoza pragmatyczna), to w odniesieniu do aktów ściśle poznawczych, tj. aktów prowadzących do wytworzenia nowej wiedzy, wątpliwości te powinny zostać bezwzględnie rozwiane (diagnoza epistemologiczna).

Rozpatrując tę kwestię dychotomicznie, należy podkreślić, że akty kognitywne, choć w płaszczyźnie komunikacji interneuronalnej jednorazowe, to jednak nie mogą być uznane za akty ściśle poznawcze (epistemiczne), tak długo, jak długo nie będą prowadziły do wytworzenia nowej wiedzy. Akty poznawcze są względne - względne w wymiarze czasowym, względne także $\mathrm{z}$ uwagi na ich jakość. Ich status czasowy i jakość zależą bowiem od tego, czy, a jeśli tak to, w jakim stopniu akty kognitywne spełniają funkcje ściśle poznawcze. O funkcjach poznawczych można zatem z całą stanowczością powiedzieć to, że są jednorazowe. Diagnozowanie tych funkcji 
należy do zadań lingwistyki, szczególnie zaś do zadań formułowanych w ramach semantyki epistemologicznej. Lingwiści nie posiadają wprawdzie w swoim repertuarze metodologicznym instrumentów diagnozy (rzeczywistych) aktów kognitywnych, w szczególności aktów stricte poznawczych, to jednak mogą, i moim zdaniem, powinni wnioskować o tych aktach na drodze indukcji, odwołując się do wyników badań innych dyscyplin, takich jak np. neurobiologia czy socjologia, oraz stosując wszelkie metody i korespondujące z nimi instrumenty, które ich do adekwatnej diagnozy tych aktów chociażby przybliżają.

\section{Bibliografia}

Alexandru, M. (1998). Zu den Megala Semadia der byzantinischen Notation. W. L. Dobszay (red.), Cantus Planus. Papers read at the 7th Meeting in Sopron 1995 (s. 17-41). Budapest: Hungarian Academy of Science/ Institut of Musicology.

Alexandru, M. (1999). Bemerkungen zu den Neumen- und Formelbezeichnungen des byzantinischen Gesanges. W. Ch. Troelsgård (red.), Palaeobyzantinische Notation II. Acta of the Congress held at Hernen Castle (the Netherlands) in October 1996 (s. 1-21). Hernen: A. A. Brediusstichting.

Alexandru, M. (2006). The Palaeography of Byzantine Music: A Brief Introduction with Some Preliminary Remarks on Musical Palimpsests. W. Á. Escobar (red.), El palimpsesto grecolatino como fenómeno librario y textual (s. 113 - 130). Zaragoza: Institución „Fernando el Católico“. [online] https://ifc.dpz.es/recursos/publicaciones/26/54/6.MariaAlexandru.pdf, [9.04.2018].

Arvanitis, I. (1997). A Way to the Transcription of Old Byzantine Chant by means of Written and Oral Tradition. W. Ch. Troelsgård (red.), Byzantine Chant. Tradition and Reform. Athens: The Danish Institute, s. 123 - 142.

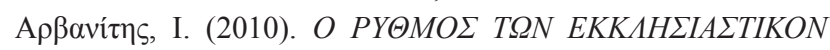

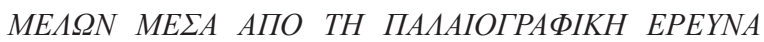

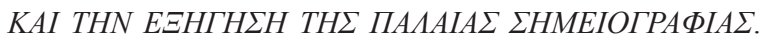

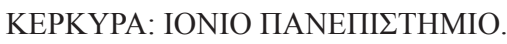

Arystoteles (2014). Retoryka. Retoryka dla Aleksandra. Poetyka. (H. Podbielski, Tłum.). Warszawa: PWN.

Borck, C. (2005). Hirnströme - Eine Kulturgeschichte der Elektroenzephalographie. Göttingen: Wallstein.

Brandenburg, Ph. (2005). Apollonios Dyskolos. Über das Pronomen. Einführung, Text, Übersetzung und Erläuterungen. München, Leipzig: K.G. Saur.

Callanan, Ch. K. (1987). Die Sprachbeschreibung bei Aristophanes von Byzanz. Göttingen: Vandenhoeck \& Ruprecht.

Domasch, S. (2007). Biomedizin als sprachliche Kontroverse. Die Thematisierung von Sprache im öfentlichen Diskurs zur Gendiagnostik. Berlin: de Gruyter.

Eichenbaum, H. (2012). The Cognitive Neuroscience of Memory. An Introduction. New York et. al.: Oxford University Press.

Engberg, S. G. (1982). Ekphonetic Chant - The Oral Tradition and The Manuscripts. W. H. Hunger (red.), Jahrbuch der Österreichischen Byzantinistik. Akten des XVI. Internationalen Byzantinistenkongresses, Wien, 4. - 9. Oktober 1981. t. 32/7/II. Akten. Symposion für Musikologie. Byzantinische Musik 1453-1832 als Quelle musikalischer Praxis und Theorie vor 1453. Leitung: Jørgen Raasted. Wien: ÖAW, s. $41-47$.
Georgiades, Th. (1939). Bemerkungen zur Erforschung der byzantinischen Kirchenmusik. Byzantinische Zeitschrift 39(1), s. $67-88$.

GEW - Griechisches Etymologisches Wörterbuch. (red.) H. Frisk, 1954 - 1972. t. 1., 1 - XXX, $1-938$ [ $\alpha-\kappa o] 1960$; t. 2., $1-1154[\kappa \rho-\omega] 1970$; t. 3., $1-312$ [Nachträge, Wortregister, Corrigenda] 1972. Heidelberg: Carl Winter Universitatis-Verlag [także online] https://archive.org/details/ hjalmar, [9.04.2018].

GLRBP - Greek Lexicon of the Roman and Byzantine Periods (from B. C. 146 to A. D. 1100) by Sophocles, E. A. (Evangelinus Apostolides), 1807-1883; Thayer, Joseph Henry, 1828-1901; Drisler, Henry, 1818-1897. [online] https://archive.org/details/cu31924021609395, [9.04.2018].

Haas, M. (1973). Byzantinische und slavische Notationen. Köln: Arno Volk-Verlag, Hans Gerig KG.

Haas, M. (2006). Griechische Musiktheorie in arabischen, hebräischen und syrischen Zeugnissen. W. K. Volk, F. Zaminer, C. Floros, R. Harmon, L. Richter i M. Haas (red.), Geschichte der Musiktheorie. Bd. 2. Vom Mythos zur Fachdisziplin: Antike und Byzanz. Darmstadt: Wiss. Buchgesellschaft, s. $635-716$.

Hannick, Ch. (1995). Byzantinische Musik. W. L. Finscher (red.), Die Musik in Geschichte und Gegenwart. 2., neubearb. Ausg. Kassel i in.: Bärenreiter, s. $288-310$.

HAWAT - Hebräisches und aramäisches Wörterbuch zum Alten Testament mit Einschaltung und Analyse aller schwer erkennbaren Formen, Deutung der Eigennamen sowie der massoretischen Randbemerkungen und einem deutsch-hebräischen Wortregister von König Eduard. Leipzig: Dieterich'sche Verlagsbuchhandlung, 1910. [online] https://archive.org/details/hebrischesunda00knuoft, [26.02.2018].

Heidler, M.-D. (2013). Das Arbeitsgedächtnis. Ein Überblick für Sprachtherapeuten, Linguisten und Pädagogen. Bad Honnef: Hippocampus.

Kahana, M. J. (2012). Foundations of Human Memory. New York $\mathrm{i}$ in.: Oxford University Press.

Kausen, E. (2010). Die indogermanischen Sprachen. Von der Vorgeschichte bis zur Gegenwart, Stuttgart: Buske.

Kostiuczuk, J., Tofiluk, J., Ławreszuk, M., Misijuk, W. i Charkiewicz, J. (red.) (2016), Specyfikacja polskiej terminologii prawosławnej. Koncepcja normatywizacji pisowni. Białystok: Wydawnictwo Uniwersytetu w Białymstoku.

Kotin, M. L. (2016). Wortsemantik - kontextabhängig oder kontextstiftend? Unter besonderer Berücksichtigung der Modalversemantik. W. P. Bąk i B. Rolek (red.), Vom Wort zum Gebrauch. Wortbedeutung und ihre Eingebu- 
ndenheit in Diskurse. Frankfurt am Main: Peter Lang, s. $15-39$.

Kowalska, D. M. (1997). Anatomiczne podstawy pamięci. W. T. Górska, A. Grabowska i J. Zagrodzka (red.), Mózg a zachowanie. Warszawa: PWN, s. 298 - 337.

KWAH - Kompaktwörterbuch Althebräisch. Althebräisch Deutsch (red.) F. Matheus. Stuttgart: Pons, 2006.

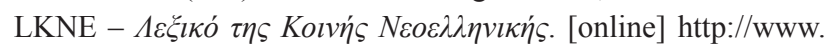
greek-language.gr/greekLang/modern_greek/tools/lexica/ triantafyllides/, [22.11.2018].

LLKO - Lexikon. Liturgie und Kunst der Ostkirche unter Berücksichtigung der alten Kirche (red.) K. Onasch. Berlin, München: Buchverl. Union, 1993.

$\Lambda$ ОГЕION - Greek and Latin Dictionary [online] http://logeion.

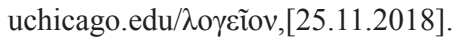

LSJ - The Online Liddell-Scott-Jones Greek-English Lexicon [online] http://stephanus.tlg.uci.edu/lsj/\#eid=1\&context=1sj, [02.03.2018].

Madytos, Ch., Chartophylax, Ch. i Terzopoulos, K. (2012). Introduction to the Method of Byzantine Chant Notation. An Englisch translation of Chourousios' revision of Chrysanthos' Eisagoge. Saint Louis: Psaltic Notes.

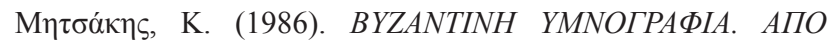

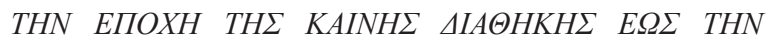

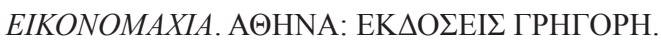

Nagórka, P. P. (2017). Realna podstawa leksykonu enologii. W. O. Borys, M. Jeż, A. Samadowa i M. Saniewska (red.), Szkice językowe i literacko-kulturowe. Warszawa, Iwano-Frankiwsk: Katedra Ukrainistyki UW, s. 73 - 93.

Nikolakopoulos, K. (2015). Die orthodoxe Kirchenmusik als ein bedeutendes Erbe von Byzanz und ihre moderne Rezeption im Westen am Beispiel des ,Byzantinischen Kantorenchores München'. RES 7(3), s. 447 - 459. [także online] https://doi. org/10.1515/ress-2015-0033, [12.06.2018].

$\mathrm{OH}$ - Orthodoxe Hymnographie. Lexikon der orthodoxen hymnologisch-musikalischen Terminologie von Konstantin Nikolakopoulos (=Liturgische Texte und Studien 2). Schliern b. Köniz: Klimmeck, 1999.

Paprocki, H. (2014). Liturgie Kościoła Prawosławnego. Kraków: M. Pawłowski, G. (2015a). Kognitiv und/ oder epistemisch. Auf dem Weg zur epistemologischen Semantik. Glottodidactica 42(1), s. 65 - 81. [także online] https://doi.org/10.14746/ gl.2015.42.1.5, [12.06.2018].

Pawłowski, G. (2015b). Zur neuen Fachlexik der byzantinischen Hymnographie und Musik in Polen. Orthodoxes Forum Zeitschrift des Instituts für Orthodoxe Theologie der Universität München 29(2), s. 165 - 176.

Pawłowski, G. (2017a). Fachlexeme in Konstruktion. Linguistischer Beitrag zur Erkenntnisarbeit. Frankfurt am Main: Peter Lang Edition.

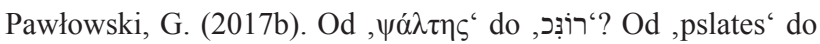
,psalta'? Dowody empiryczne pracy poznawczej tłumacza - sprawcy polskich leksemów specjalistycznych z zakresu hymnografii i muzyki bizantyjskiej. Lingwistyka Stosowana 21(1), s. $95-114$.

Pawłowski, Grzegorz (2018). Fach- und Wissenschaftssprache der byzantinischen Hymnographie und Musik (in Polen). Quelle(n) - Normung - Kontroversen. Orthodoxes Forum - Zeitschrift des Instituts für Orthodoxe Theologie der Universität München 32(1), s. 53 - 61.

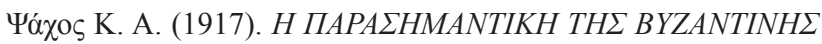

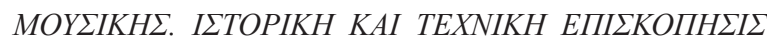

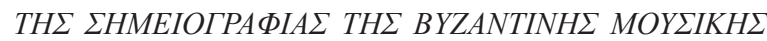

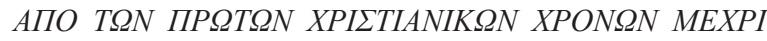

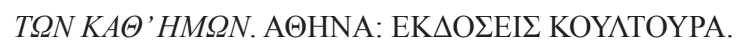

Richter, L. (1998). Antike Überlieferungen in der byzantinischen Musiktheorie. Acta Musicologica 70(2), s. 133 - 208.

SGP - Stownik Grecko-Polski (red.) Oktawiusz Jurewicz. Warszawa: Sub Lupa, 2015.

Siegel J. D. (2006). Entwicklungspsychologie, interpersonale und neurobiologische Dimensionen des Gedächtnisses. W. H. Welzer i H. J. Markowitsch (red.), Warum sich Menschen erinnern können. Fortschritte der interdisziplinären Gedächtnisforschung. Stuttgart: Klett-Cotta, s. $19-49$.

Rudy, J. W. (2014). The Neurobiology of Learning and Memory. Sunderland, Mass.: Sinauer.

Wellesz, E. (1961). A History of Byzantine Music and Hymnography. Oxford: Oxford University Press.

Wellesz, E. (2000). Byzantinische Musik: Ein Vortrag, herausgegeben von Gerda Wolfram. Wien: ÖAW.

Wellesz, E. (2006). Historia muzyki i hymnografii bizantyjskiej. (M. Kaziński, Tłum.). Kraków: Homini.

Welzer, H. (2006). Über Engramme und Exogramme. Die Sozialität des autobiographischen Gedächtnisses. W. H. Welzer i H. J. Markowitsch (red.), Warum sich Menschen erinnern können. Fortschritte der interdisziplinären Gedächtnisforschung. Stuttgart: Klett-Cotta, s. $111-128$.

WHB - Wortschatz der Hebräischen Bibel. 2500 Vokabeln alphabetisch und thematisch geordnet mit Register deutsch -hebräisch. 5. Aufl. (red.) S. Arnet. Zürich: Theologischer Verlag Zürich, 2013.

WSHA - Wielki Stownik Hebrajsko-Polski i Aramejsko-Polski (red.) L. Koehler, W. Baumgartner i J. J. Stamm. t. 1 - 2. Warszawa: Vocatio, 2001.

WMK05 - Wywiad z Maciejem Kazińskim na temat terminu

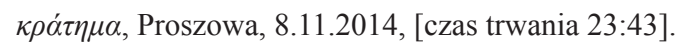

Wolfram, G. (2000). Kommentar zu Egon Wellesz' Byzantinische Musik. W. G. Wolfram (red.), Byzantinische Musik: Ein Vortrag. Wien: ÖAW, s. $35-59$. 
ISSN 1508-7719

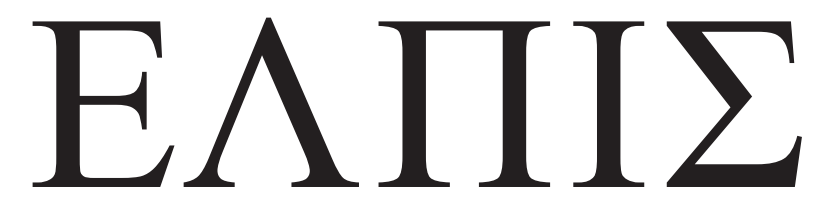

CZASOPISMO TEOLOGICZNE KATEDRY TEOLOGII PRAWOSŁAWNEJ UNIWERSYTETU W BIAŁYMSTOKU

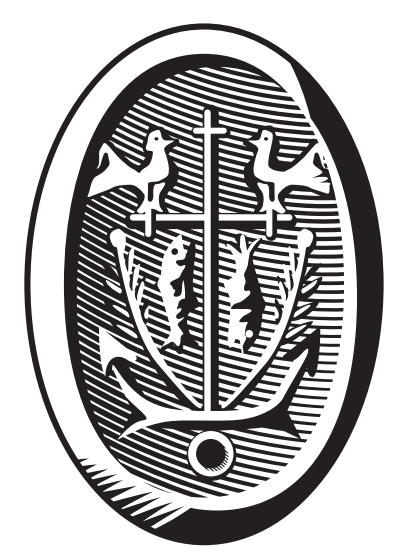

ADRES REDAKCJI

ul. Ludwika Zamenhofa 15, 15-435 Białystok, Polska tel. 85 745-77-80, e-mail: elpis@uwb.edu.pl www.elpis.uwb.edu.pl 